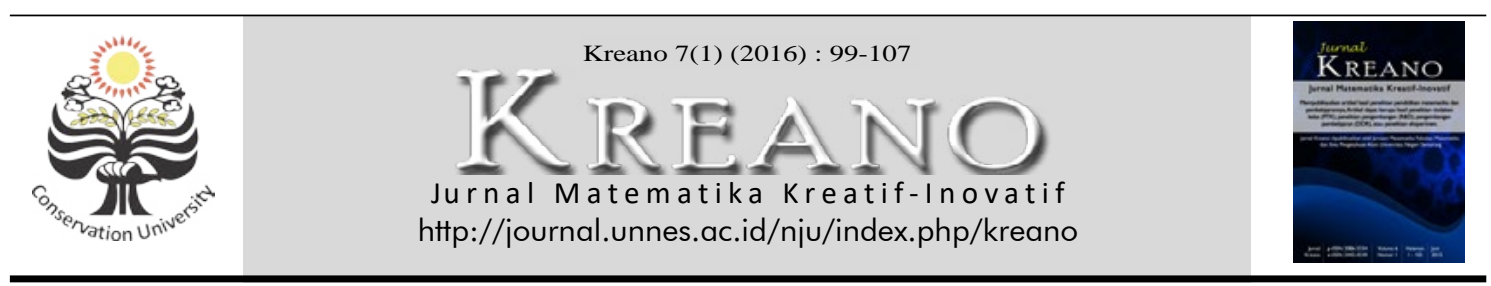

\title{
Penggunaan Media Software GeoGebra untuk Meningkatkan Kemampuan Representasi Matematis Siswa SMP Kelas VIII
}

\author{
Marini Oktaria' ${ }^{1}$, Akhmad Khairil Alam², Sulistiawati ${ }^{3}$
}

\author{
1,2,3Program Studi Pendidkan Matematika, \\ Sekolah Tinggi Keguruan dan Ilmu Pendidikan Surya, Indonesia \\ Coresponding Author Email: 'marini.oktaria@students.stkipsurya.ac.id \\ Author Email: ${ }^{2}$ akhmad.khairil@students.stkipsurya.ac.id \\ Author Email: ${ }^{3}$ sulistiawati@stkipsurya.ac.id
}

DOI: http://dx.doi.org/10.15294/kreano.v7i1.5014

Received : January 2016; Accepted: March 2016; Published: June 2016

\begin{abstract}
Abstrak
Penelitian ini bertujuan untuk mengetahui apakah software GeoGebra dapat meningkatkan kemampuan representasi matematis siswa pada materi SPLDV. Sampel dalam penelitian ini adalah siswa kelas VIII.2 SMP Islamic Village tahun ajaran 2015/2016 semester II sebanyak 24 orang dengan purposive sampling. Instrumen penelitian berupa tes uraian untuk mengukur kemampuan representasi matematis. Metode dalam penelitian ini adalah metode kuantitatif jenis pra eksperimen dengan one group pretest-posttest design. Analisis data penelitian ini menggunakan uji non-parametrik Wilcoxon Signed Ranks Test. Hasil penelitian menunjukkan bahwa penggunaan media software GeoGebra dapat meningkatkan kemampuan representasi matematis siswa pada materi sistem persamaan linier dua variabel (SPLDV). Dari hasil pretest diperoleh nilai tertinggi hanya mampu mencapai nilai 45 dari skor maksimal 100, dimana 10 siswa mendapatkan nilai dibawah 20 dan dari hasil posttest diperoleh nilai tertinggi mencapai 100 dari skor maksimal 100, dengan 18 siswa mendapatkan nilai di atas 75. Peningkatan yang diperoleh berada pada kategori sedang sebesar 0,651. Adapun faktor yang mempengaruhi peningkatan kemampuan representasi matematis menggunakan GeoGebra yaitu GeoGebra dapat menampilkan grafik persamaan garis dengan jelas, akurat dan cepat.
\end{abstract}

\begin{abstract}
This research aims to know whether GeoGebra can increase students' mathematical representation ability at System of Linear Equation in Two Variables or not. The sample in this research is 29 students of class VIII. 2 in the second semester of academic year 2015/2016 at Islamic Village Junior High School by using purposive sampling. Essay test is used as a research instrument to measure mathematical representation ability. This is pre-experimental research with one group pretest posttest design. Non-parametric test Wilcoxon Signed RankTest is used to analyze the data in this research. The result of this research showed that the using of GeoGebra can increase students' mathematical representation ability at System of Linear Equation in Two Variables. From the results obtained the highest score pretest only able to reach a maximum value of 45 from 100, where 10 students scored below 20 and the results obtained posstest highest value reached 100 out of a maximum score of 100 , with 18 students scoring above 75 . Increasing obtained in middle category amounted to 0,651. The factors that influence the increased ability to use mathematical representation that GeoGebra display graphics line equation with clear, accurate and fast.
\end{abstract}

Keywords: GeoGebra, mathematical representation, system of linier equation in two variables

\section{PENDAHULUAN}

Untuk menyambut tantangan zaman yang terus berkembang setiap saat maka, perlu adanya peningkatan sumber daya manusia sehingga kita dapat bersaing dalam ranah in- ternasional. Salah satu bidang yang dapat kita gunakan sebagai jembatan untuk meningkatkan sumber daya manusia yang berkualitas adalah dalam dunia pendidikan. Salah satu cabang ilmu pengetahuan yang memegang 
peranan penting dalam dunia pendidikan adalah matematika. Artha, et al (2014) menjelaskan bahwa matematika merupakan alat untuk mengembangkan kemampuan berpikir siswa. Adapun kemampuan berpikir matematis yang harus dimiliki oleh siswa menurut NCTM (2000) ada lima yaitu kemampuan pemecahan masalah, kemampuan komunikasi, kemampuan koneksi, kemampuan penalaran dan kemampuan representasi. Akan tetapi pada kenyataanya kemampuan matematis siswa masih tergolong rendah. Hal ini dapat dilihat dari beberapa survey yang dilakukan oleh TIMMS dan PISA.

Berdasarkan laporan TIMMS 2011 (Provasnik et al, 2012) siswa kelas VIII Indonesia menempati posisi ke 38 diantara 42 negara yang berpartisipasi dalam tes matematika dengan skor rata-rata 406 sedangkan skor standar rata-rata internasional adalah 500 . Hasil survey TIMMS tentang kemampuan matematis siswa Indonesia ternyata tidak jauh berbeda dengan hasil survey dari lembaga lain seperti PISA (Programme International for Student Assesment). Berdasarkan hasil survey PISA 2012, kemampuan matematis siswa Indonesia menempati ranking 64 dari 65 negara dengan rata-rata skor yang diperoleh 375 , padahal rata-rata skor internasional yang ditetapkan PISA adalah 494. Hal ini terjadi karena kemampuan siswa dalam mengungkapkan gagasan atau ide-ide matematik serta merepresentasikan ekspresi matematik maupun visual masih kurang karena masih banyak kendala yang dialami siswa dalam pencapaian kemampuan representasi matematis.

Rangkuti (2014), mengatakan bahwa representasi matematis merupakan penggambaran, penterjemahan, pengungkapan, penunjukan kembali, pelambangan atau bahkan pemodelan dari ide, gagasan, konsep matematik, dan hubungan diantaranya yang termuat dalam suatu konfigurasi, konstruksi atau situasi masalah tertentu yang ditampilkan siswa dalam bentuk beragam sebagai upaya memperoleh kejelasan makna, menunjukkan pemahamannya atau mencari solusi dari masalah yang dihadapinya. Dari pengertian representasi matematis di atas maka dapat dikatakan bahwa kemampuan representasi matematis merupakan kemampuan yang penting untuk dimiliki siswa agar dapat memahami konsep matematika dengan baik. Hal ini juga dipertegas oleh Kartini (2009) yang mengatakan bahwa representasi sangat berperan penting dalam peningkatan pemahaman konsep matematika. Adapun beberapa bentuk representasi matematis seperti verbal, gambar, numerik, simbol aljabar, tabel, diagram, dan grafik merupakan bagian yang tak dapat dipisahkan dalam pembelajaran matematika.

Kemampuan representasi matematis diukur dari ketercapaian indikatornya. Menurut Sumarmo (2010) indikator kemampuan representasi matematis yaitu: 1) mencari hubungan berbagai representasi konsep dan prosedur, 2) memahami hubungan antar topik matematika, 3) menerapkan matematika dalam bidang lain atau dalam kehidupan sehari-hari, 4) memahami representasi ekuivalen suatu konsep, 5) mencari hubungan satu prosedur dengan prosedur lain dalam kehidupan sehari-hari, dan 6) menerapkan hubungan antar topik matematika. Sedangkan menurut Mudzakir (2006) indikator yang digunakan untuk menilai kemampuan representasi matematis siswa terlihat pada Tabel 1.

Dari beberapa pemaparan tentang indikator kemampuan diatas maka indikator kemampuan representasi matematis yang akan digunakan dalam kegiatan penelitian ini meliputi yaitu: 1) menjelaskan secara matematis, masuk akal dan tersusun sistematis.; 2) menggambar grafik persamaan garis beserta unsur-unsurnya secara lengkap dan benar untuk mencari himpunan penyelesaiannya.; 3) membuat model matematika.

Salah satu faktor yang mempengaruhi kemampuan representasi matematis siswa adalah penggunaan media pembelajaran yang mendukung siswa dalam memvisualisasikan atau merepresentasikan permasalahan matematika. Hal ini sesuai dengan pernyataan yang diungkapkan oleh Nursanti, dkk (2015) bahwa dengan menggunakan media pembelajaran berbasis teknologi akan mempermudah proses pembelajaran sehingga dapat meningkatkan kualitas pembelajaran dan dapat meningkatkan kemampuan representasi matematis siswa. Salah satu media pembelajaran matematika berbasis teknologi 
Tabel 1. Indikator Kemampuan Representasi Matematis

\begin{tabular}{|c|c|}
\hline Representasi & Bentuk-Bentuk Operasional \\
\hline $\begin{array}{l}\text { Representasi Visual } \\
\text { (Diagram, tabel atau grafik) }\end{array}$ & $\begin{array}{l}\text { Menyajikan kembali data atau informasi dari suatu representasi ke rep- } \\
\text { resentasi diagram, grafik atau tabel. } \\
\text { Menggunakan representasi visual untuk mneyelesaikan masalah } \\
\text { Membuat gambar untuk memperjelas masalah dan memfaasilitasi } \\
\text { peneyelesaian. }\end{array}$ \\
\hline $\begin{array}{l}\text { Persamaan atau ekspresi } \\
\text { matematis }\end{array}$ & $\begin{array}{l}\text { Membuat persamaan, model matematik atau representasi dari } \\
\text { repersentasi lain yang diberikan. } \\
\text { Meneyelesaikan masalah dengan melibatkan ekspresi matematik }\end{array}$ \\
\hline Kata-kata atau teks tertulis & $\begin{array}{l}\text { Membuat situasi masalah berdasarkan data atau representasi yang } \\
\text { diberikan. } \\
\text { Menuliskan interpretasi dari suatu representasi } \\
\text { Menuliskan langkah-langkah penyelesaian maslaah matematika den- } \\
\text { gan kata-kata. } \\
\text { Menjawab soal dengan menggunakan kata-kata atau teks tertulis. }\end{array}$ \\
\hline
\end{tabular}

yang dapat membantu siswa dalam merepresentasikan permasalahan matematika adalah software GeoGebra. Salah satu media pembelajaran yang dapat merepresentasikan model matematika atau merepresentasikan persamaan linier dua variabel ke dalam bentuk grafik yaitu dengan menggunakan bantuan media software GeoGebra. Menurut Hohenwarter et al (2008) GeoGebra adalah software matematika dinamis yang menggabungkan geometri, aljabar, dan kalkulus. Sedangkan menurut Wulandari (2015) GeoGebra adalah software matematika yang mudah digunakan, baik pada materi geometri, aljabar, dan kalkulus. Dari beberapa pengertian GeoGebra diatas dapat disimpulkan bahwa GeoGebra merupakan salah satu software matematika yang dapat digunakan dalam pembelajaran matematika yang meliputi materi geometri, aljabar, dan kalkulus. GeoGebra berfungsi sebagai media pembelajaran matematika yang dapat membantu siswa secara visual untuk memahami materi matematika yang besifat abstrak. Tidak hanya itu GeoGebra juga dapat membantu siswa dalam memahami konsep grafik garis lurus secara lebih rinci dengan tampilan yang variatif dan menarik. Selain itu bagi guru sendiri, GeoGebra dapat digunakan sebagi alat bantu pembelajaran matematika untuk menciptakan pembelajaran yang interaktif yang memungkinkan siswa mengeksplorasi berbagai konsep-konsep matematika bersifat abstrak.

Menurut Hohenwarter \& Fuchs (2004), GeoGebra sangat bermanfaat sebagai media pembelajaran matematika dengan beragam aktivitas sebagai berikut : (1) Sebagai media demonstrasi dan visualisasi. Dalam hal ini, dalam pembelajaran matematika yang bersifat tradisional, guru memanfaatkan GeoGebra untuk mendemonstrasikan dan memvisualisasikan konsep-konsep matematika tertentu; (2) Sebagai alat bantu konstruksi. Dalam hal ini GeoGebra digunkan untuk memvisualisasikan konstruksi konsep matematika tertentu, misalnya mengkonstruksi lingkaran dalam maupun luar segitiga, atau garis singgung; (3) Sebagai alat bantu proses penemuan. GeoGebra digunakan untuk alat bantu bagi siswa untuk menemukan suatu konsep mateamtis, misalnya tempat kedudukan titi-titik atau karakteristik parabola.

Berdasarakan manfaat GeoGebra sebagai media pembelajran matematika maka dapat dikatakan bahwa media software GeoGebra dapat digunakan untuk membantu siswa dalam memahami materi sistem persamaan linier dua variabel (SPLDV). Hal ini diperkuat dengan hasil penelitian yang telah dilakukan oleh Astuty \& Rudhito (2012) yang mengemukakan bahwa software GeoGebra dapat mengatasi kesulitan belajar siswa terutama dalam memvisualisasikan grafik garis lurus yang berhubungan erat dengan materi sistem persamaan linier dua variabel (SPLDV).

Salah satu pokok bahasan dalam matematika yang menuntut kemampuan representasi matematis yaitu sistem persamaan linier dua variabel (SPLDV). Hal ini senada dengan Nursanti, dkk (2015) yang menjelaskan bahwa 
satu di antara penggunaan representasi matematis dalam matematika terdapat pada materi SPLDV. Pada materi SPLDV siswa dituntut untuk merepresentasikan masalah matematika yang berkaitan dengan kehidupan seharihari ke dalam model matematika. Dalam materi SPLDV contoh soalnya adalah sebagai berikut: harga tiga pensil dan dua buku tulis adalah Rp. 12.000 sedangkan harga dua pensil dan 4 buku tulis adalah Rp. 16.000. Tentukanlah model matematika dari soal tersebut. Dalam materi SPLDV siswa tidak hanya dituntut untuk membuat model matematika tetapi juga dapat mencari penyelesaian dari model matematika yang diberikan. Dalam SPLDV ada tiga metode yang dapat digunakan untuk mencari penyelesaian yang berkaitan dengan masalah model matematika yaitu, metode grafik, metode eliminasi dan metode substitusi. Metode grafik merupakan salah satu cara penyelesaian soal SPLDV dengan cara menggambarkan model matematika yang diberikan ke dalam bentuk grafik dan mencari titik potong dari model matematika yang diberikan sehingga didapatkan himpunan penyelesaian yang memenuhi sebagai solusi dari masalah yang berkaitan dengan SPLDV.

Berdasarkan pemaparan latar belakang masalah maka didapatkan rumusan masalah pada kegiatan penelitian ini yaitu, apakah penggunaan media software GeoGebra dapat meningkatkan kemampuan representasi matematis siswa SMP kelas VIII. Dari rumusan masalah diatas, maka tujuan dari kegiatan penelitian ini adalah untuk mengetahui apakah penggunaan media software GeoGebra dapat meningkatkan kemampuan representasi matematis siswa SMP kelas VIII. Adapun manfaat dari penelitian ini antara lain: 1) dapat memberi bentuk pembelajaran SPLDV menggunakan media software GeoGebra yang dapat diterapkan untuk meningkatkan kemampuan representasi matematis siswa; 2) membantu siswa dalam memvisualisasikan atau merepresentasikan persamaan atau model matematika dalam bentuk grafik ataupun sebaliknya; 3) menambah wawasan dalam dunia pendidikan sehingga ke depannya dapat dikembangkan lagi alat bantu pembelajaran yang lebih inovatif.

\section{METODE}

Penelitian ini dilaksanakan di kelas VIII.2 SMP Islamic Village Tangerang dengan jumlah siswa sebanyak 29 orang. Teknik pengambilan sampel dalam penelitian ini menggunakan teknik purposive sampling. Metode yang digunakan adalah metode pre-experimental design dengan one group pre-test and post-test design. Melalui desain ini akan dilihat peningkatan kemampuan representasi matematis siswa sebelum diajarkan dan setelah diajarkan dengan menggunakan bantuan media software GeoGebra. Variabel bebas dalam penelitian ini adalah penggunaan software GeoGebra sedangkan variabel terikatnya ialah kemampuan representasi matematis siswa. Desain penelitian ini menggunakan satu kelompok subjek tanpa kelompok pembanding. Adapun desain penelitian ini dapat dilihat pada Tabel 2.

Tabel 2. Desain Penelitian

\begin{tabular}{cccc}
\hline Subjek & Pre-test & Perlakuan & Post-tset \\
\hline $\begin{array}{c}\text { Siswa Ke- } \\
\text { las VIII.2 }\end{array}$ & $\mathrm{T}_{1}$ & $\mathrm{X}$ & $\mathrm{T}_{2}$ \\
\hline
\end{tabular}

Desain penelitian ini dipilih karena beberapa pertimbangan yaitu dalam desain penelitian ini tidak membutuhkan waktu yang lama. Akan tetapi dalam desain penelitian ini terdapat kekurangan yaitu perlakuan yang diberikan bukan satu-satunya faktor yang menyebabkan perbedaan antara pre-test dan post-test kemudian hasil dari desain penelitian ini lemah. Adapun tahapan pelaksanaan dalam penelitian terdiri dari beberapa tahap yaitu tahap pertama merupakan tahapan persiapan dengan dilakukannya uji validitas instrumen, kemudian tahap kedua yaitu pelaksanaan dengan melakukan pre-test, pembelajaran, dan diberikan post-test dan tahap yang terakhir yaitu analisis data dengan menggunakan uji statistik non parametrik Wilcoxon Signed-RankTest.

Instrumen yang digunakan dalam penelitian ini adalah tes kemampuan representasi matematis pada materi sistem persamaan linier dua variabel yang telah diuji validitasnya oleh pakar dan diujikan juga validitasnya kepada siswa kelas IX SMP Alia Islamic School Tangerang. Soal pre-test dan post-test 
terdiri dari 5 butir soal uraian. Soal pre-test digunakan untuk mengetahui sejauh mana kemampuan dan kesiapan siswa terhadap materi yang akan diajarkan. Sedangkan soal post-test digunakan untuk melihat apakah terjadi peningkatan kemampuan representasi matematis siswa setelah dilakukan pembelajaran dengan bantuan software GeoGebra.

Data yang akan dianalisis pada penelitian ini berasal dari nilai pre-test dan post-test yang telah dilakukan sebelum dan setelah pembelajaran menggunakan software GeoGebra. Berdasarkan nilai pre-test dan post-test tersebut, kemudian dihitung seberapa besar peningkatan yang terjadi pada siswa dengan menghitung $\mathrm{n}$-gain. Perhitungan data analisis $\mathrm{N}$-Gain dengan menggunakan gain ternormalisasi yang dikembangkan oleh Meltzer (2002), sebagai berikut:

$$
g=\frac{\text { skor posttest }- \text { skor pretest }}{\text { skor ideal }- \text { skor pretest }}
$$

Tabel 3. Kriteria Skor N-Gain Ternormalisasi

\begin{tabular}{cc}
\hline Skor N-Gain & Interpretasi \\
\hline $0,7<\mathrm{g} \leq 1,0$ & Tinggi \\
$0,3<\mathrm{g} \leq 0,7$ & Sedang \\
$\mathrm{g} \leq 0,3$ & Rendah \\
\hline
\end{tabular}

Pengujian hipotesis penelitian ini menggunakan Wilcoxon Signed-Rank Test, karena data penelitian merupakan data tunggal dan sampel tidak berdistribusi normal. Pengujian hipotesis peneliti menggunakan nilai alpha sebesar 0,05 atau dengan kata lain memiliki tingkat kepercayaan 95\%. Dalam melakukan pengolahan data ini, peneliti menggunakan software SPSS (Statistical Product and Service Solution) versi 18.0 for windows, yang dapat mengolah dan memproses data secara cepat dan akurat. Cara menarik kesimpulan dengan Wilcoxon Signed-Rank Test menurut Santoso (2001) adalah dengan membandingkan antara Asymp. Sig $(p)$ dan nilai alpha yang sebesar 0,05 . Jika $p>0,05$ maka hipotesis awal diterima. Jika $p<0,05$ maka hipotesis awal ditolak.

\section{HASIL DAN PEMBAHASAN}

\section{Hasil}

Penelitian ini diawali dengan melakukan uji coba instrumen kepada 24 siswa kelas IV SMP Alia Islamic School Komplek Dasana Indah Blok $\mathrm{SO}_{5}$ Kelapa Dua Tangerang dengan sebanyak 245 soal tipe uraian. Analisis hasil uji coba instrumen ini menggunakan software anates versi 4.05. Hasil dari analisis uji coba instrumen yang diperoleh, dapat di lihat pada tabel 4 .

Dari tabel di atas diperoleh reliabilitas tinggi dengan hasil perhitungan sebesar 0,80. Semua soal digunakan untuk penelitian setelah dilakukan perbaikan untuk butir soal nomor 2 dan 5 .

Penelitian ini bertujuan untuk mengukur peningkatan kemampuan representasi matematis siswa yang belajar materi Sistem Persamaan Linear Dua Variabel (SPLDV) menggunakan media software geogebra. Indikator yang diukur meliputi kemampuan: 1) menjelaskan secara matematis, masuk akal, dan tersusu sistematis, 2) menggambar grafik persamaan garis beserta unsur-unsurnya secara lengkap dan benar untuk mencari himpunan penyelesaiannya, dan 30 membuat model matematika. Hasil skor kemampuan representasi matematis siswa untuk pretest dan

Tabel 4. Hasil Analisis Uji Coba Instrumen

\begin{tabular}{|c|c|c|c|c|c|}
\hline $\begin{array}{c}\text { Nomor } \\
\text { Butir } \\
\text { Soal }\end{array}$ & Validitas & Reliabilitas & $\begin{array}{c}\text { Daya } \\
\text { Pembeda }\end{array}$ & $\begin{array}{c}\text { Tingkat } \\
\text { Kesukaran }\end{array}$ & Ket. \\
\hline 1 & Valid & & Baik & Sedang & Dipakai \\
\hline 2 & $\begin{array}{l}\text { Tidak } \\
\text { valid }\end{array}$ & & $\begin{array}{l}\text { Sangat } \\
\text { jelek }\end{array}$ & Sukar & Diperbaiki \\
\hline 3 & Valid & Tinggi & Baik & Sedang & Dipakai \\
\hline 4 & Valid & & Baik & Sedang & Dipakai \\
\hline 5 & $\begin{array}{l}\text { Tidak } \\
\text { valid }\end{array}$ & & Cukup & Sukar & Diperbaiki \\
\hline
\end{tabular}


postest dapat dilihat pada tabel 5 di bawah ini.

Dari tabel di atas terlihat bahwa rata-ra-

ta kemampuan representasi matematis siswa untuk pretest adalah 18,79 sedangkan untuk postest adalah 69,66 dari skor idealnya 100 . Tampak bahwa rata-rata kemampuan representasi postest lebih besar daripada pretets. Besarnya standar deviasi untuk skor pretest adalah 11,23 sedangkan untuk skor posttest adalah 27,84. Terlihat bahwa penyebaran data postest lebih besar daripada data pretes, dengan kata lain pada skor postest datadatanya lebih menjauhi rata-rata dibandingkan dengan pretest. Hal ini disebabkan oleh adanya peningkatan yang tidak merata pada setiap siswa. Rata-rata pretest siswa sebesar 18,79 dari 100, dapat kita katakan berada pada level yang rendah karena siswa hanya menguasai kurang dari 20\% dari materi yang harus dikuasai.

Meskipun rata-rata postest kemampuan representasi matematis lebih besar daripada rata-rata postestnya, kita tidak tahu persis apakah perbedaan ini signifikan. Untuk itu, dilakukan pengjian beda rata-rata kemampuan representasi matematis dengan taraf signifikansi ( $\alpha$ ) $5 \%$. Uji statistik yang digunakan adalah uji-t untuk jenis dua kelompok sampel yang berpasangan (two related sample). Sundayana (2014) menyatakan bahwa arti dari sampel berpasangan adalah satu sampel dengan subjek sama namun diberikan dua jenis pengkuruan atau dua jenis perlakuan. Syarat pengujian dalam penelitian ini adalah uji normalitas. Pengujian normalitas ini dilakukan untuk data pretest dan data postest. Uji normalitas dalam penelitian menggunakan software SPSS versi 18.0 for windows. Krite- ria terima $\mathrm{H}_{\circ}$ pada taraf signifikansi $\alpha=5 \%$ adalah apabila sig. $>\alpha$. Oleh karena banyaknya sampel dalam penelitian ini 30 ke bawah $(n \leq B)$ ) maka menggunakan uji One Sample Saphiro Wilk. Data selengkapnya dari output SPSS dapat dilihat pada tabel 6 di bawah ini.

Dari tabel di atas diperoleh nilai sig. Pretest $=0,029$ dan nilai sig. Post-test $=0,004$. Baik pre-test maupun post-test nilai sig. $<\alpha$ , sehingga data tidak berdistribusi normal. Karena kedua skor pre-test dan post-test tidak berdistribusi normal maka uji hipotesis yang digunakan adalah uji non parametrik yaitu Wilcoxon Signed-RankTest.

\section{Pembahasan}

Dari hasil pretest diperoleh nilai tertinggi hanya mampu mencapai nilai 45 dari skol maksimal 100, dimana 10 siswa mendapatkan nilai dibawah 20. Hal ini menunjukkan bahwa siswa belum begitu paham mereprepresentasikan pada materi sistem persamaan linier dua variabel, padahal sebelum siswa belajar materi tersebut, siswa telah belajar tentang materi persamaan garis lurus yang sudah mereka terima dari guru kelasnya sebelum masuk materi sistem persamaan linier dua variabel, dimana pada materi persamaan garis lurus siswa belajar untuk menggambar garis lurus dari persamaan yang diberikan yang merupakan representasi dari materi sistem persamaan linier dua variabel. Berdasarkan pengamatan peneliti rendahnya kemampuan representasi siswa disebabkan oleh pembelajaran yang diterapkan guru dikelas menggunakan metode konvensional tipe ceramah yang membuat siswa merasa bosan saat belajar dan juga siswa kesulitan dalam menerima penjelasan ke-

Tabel 5. Statistika deskriptif Data Pre-test dan Post-test Kemampuan Representasi Matematis

\begin{tabular}{ccccccc}
\hline & $N$ & $X_{\text {min. }}$ & $X_{\text {maks. }}$ & $\bar{X}$ & $S$ \\
\hline Pre-test & 24 & 5 & 45 & 18,79 & 11,23 \\
Post-test & 24 & 5 & 100 & 69,66 & 27,84 \\
\hline \multicolumn{7}{c}{ Tabel 6. Uji Normalitas } \\
\hline Pre-test & 0,162 & 24 & 0,049 & 0,919 & 24 & 0,029 \\
Post-test & 0,197 & 24 & 0,006 & 0,885 & 24 & 0,004 \\
\cline { 2 - 8 }
\end{tabular}


tika guru menggambar di papan tulis. Hal ini terlihat dari hasil temuan unik pada hasil pretest siswa sulitnya siswa dalam merepresentasikan persamaan garis lurus. Hal ini terlihat dari hasil temuan unik pada hasil pretest siswa pada Gambar 1.

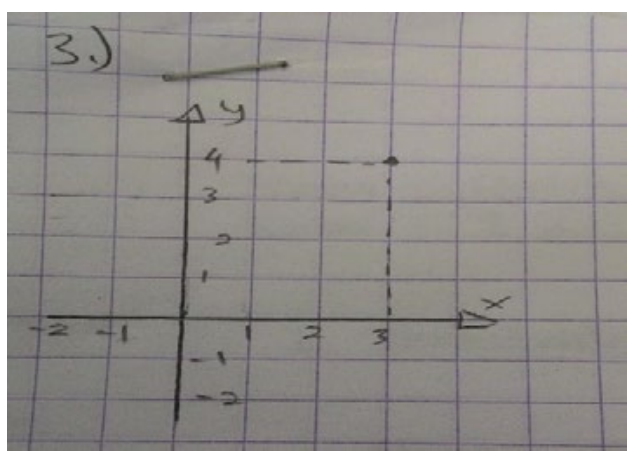

Gambar 1. Lembar pekerjaan siswa untuk soal pretest

Gambar 1 di atas merupakan hasil pekerjaan salah satu siswa pada saat pretest, siswa tidak mampu menggambar grafik persamaan garis.

Siswa diberi perlakuan selama tiga hari, pada hari pertama dilakukan tes awal dan pemberian materi menggunakan Geogebra, berdasarkan pengamatan peneliti siswa merasa senang dan antusias saat pembelajaran. Hari kedua siswa diberikan materi dan mengerjakan latihan-latihan soal, terlihat siswa berani untuk menjelaskan hasil pekerjaannya didepan kelas. Hari ketiga siswa diberikan materi lalu dilanjutkan posttest, siswa terlihat percaya diri ketika mengerjakan soal.

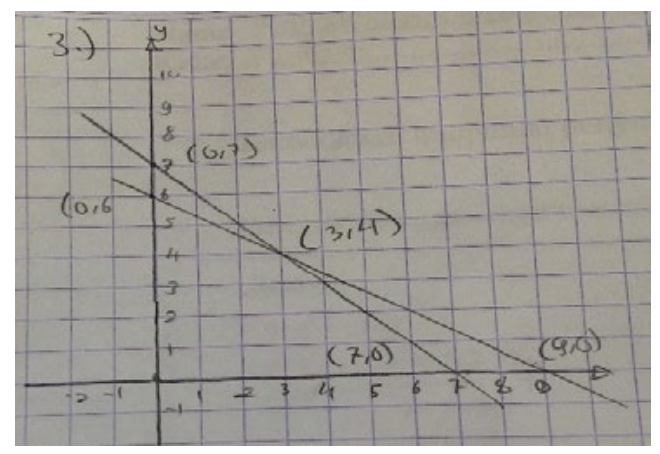

Gambar 2. Lembar pekerjaan siswa untuk soal posttest

Gambar 2 di atas merupakan hasil pe- kerjaan salah satu siswa pada saat posttest, siswa mampu menggambar grafik persamaan garis dan mampu menentukan titik potong kedua garis. Setelah dilakukan posttest diperoleh nilai tertinggi mencapai 100 dari skor maksimal 100, dengan 18 siswa mendapatkan nilai di atas 75. Hal ini disebabkan pembelajaran dengan berbantuan GeoGebra lebih efisien karena dapat menampilkan grafik persamaan garis dengan jelas, akurat dan cepat. Sehingga dengan GeoGebra siswa lebih mudah memahami representasi dari sebuah persamaan garis. Dapat disimpulkan bahwa pembelajaran berbantuan GeoGebra dapat memperngaruhi kemampuan representasi matematis siswa. Akan tetapi ada beberapa siswa yang tidak mengalami peningkatan nilai yang sigifikan, dikarenakan beberapa faktor diantaranya posisi tempat duduk siswa yang jauh dari posisi tampilan layar sehingga menyebabkan siswa kesulitan dalam memperhatikan penjelasan yang disampaikan oleh peneliti. Secara statistika, pengaruh pembelajaran menggunakan software Geogebra terhadap kemampuan representasi matematis siswa dapat dilihat dari hasil pengujian pada Tabel 7 dan Tabel 8 di bawah ini.

Tabel 7. Wilcoxon Signed Ranks Test

\begin{tabular}{clccc}
\hline & N & $\begin{array}{c}\text { Mean } \\
\text { Rank }\end{array}$ & $\begin{array}{c}\text { Sum of } \\
\text { Ranks }\end{array}$ \\
\hline \multirow{4}{*}{$\begin{array}{l}\text { Negative } \\
\text { Pretest }\end{array}$} & $\begin{array}{l}\text { Ranks } \\
\text { Positive }\end{array}$ & $20^{\mathrm{b}}$ & 100 &, 00 \\
& Ranks & 24,50 & 406,00 \\
& Ties & $1^{\mathrm{c}}$ & & \\
\cline { 2 - 5 } & Total & 29 & & \\
\hline
\end{tabular}

a. Postest < Pretest

b. Postest $>$ Pretest

c. Postest $=$ Pretest

Tabel 8. Wilcoxon Signed Ranks Test

Posttest - Pretest

Asymp. Sig. (2-tailed)

, 000

Dari tabel output di atas diperoleh nilai $W_{\text {hitung }}=0,0$ (ditunjukkan jumlah rank terkecil) dan nilai $Z_{\text {hitung }}=-4,634$ dengan 
nilai asymp. sig (2-tailed) $=0,00$. Karena nilai sig. $=0,00<0, \sigma=\alpha$ maka $\mathrm{H}_{0}$ ditolak. Hal ini berarti terdapat perbedaan rata-rata kemampuan representasi matematis siswa yang signifikan antara sebelum dan sesudah diberi pembelajaraan menggunakan software GeoGebra.

Selanjutnya untuk mengetahui apakah perbedaan ini meningkat atau tidak dapat dilihat dari skor N-Gain. Dari hasil analisis diperoleh statistik deskriptif skor N-Gain. Untuk lebih jelasnya dapat dilihat pada Tabel 9 di bawah ini.

Tabel 9. Statistik Deskriptif Data N-Gain Kemampuan Representasi Matematis

\begin{tabular}{lccccc}
\hline & $\mathrm{N}$ & $\mathrm{x}_{\text {min. }}$ & $\mathrm{x}_{\text {maks. }}$ & $\bar{X}$ & $\mathrm{~S}$ \\
\hline $\begin{array}{c}\text { Skor N-Gain } \\
\text { Kemampuan }\end{array}$ & 24 & 0 & 1 & 0,651 & 0,292 \\
$\begin{array}{c}\text { Representasi } \\
\text { Matematis }\end{array}$ & & & & & \\
\hline
\end{tabular}

Dari tabel di atas di peroleh rata-rata skor N-Gain sebesar 0,651 dengan standar deviasinya 0,292. Skor N-Gain tersebut menunjukkan bahwa kemampuan representasi matematis siswa yang memperoleh pembelajaran dengan software GeoGebra meningkat. Skor peningkatan ini sebesar 0,651 yang berada pada kategori sedang. Sehingga, dapat disimpulkan bahwa pembelajaran dengan menggunkan software Geogebra dapat meningkatkan kemampuan representasi matematis siswa.

\section{PENUTUP}

\section{Simpulan}

Berdasarkan hasil penelitian dan pembahasan diperoleh bahwa terdapat perbedaan ratarata kemampuan representasi matematis siswa siswa yang signifikan antara sebelum dan sesudah diberi pembelajaraan menggunakan software GeoGebra. Hal ini berarti pembelajaran matematika dengan software GeoGebra pada materi SPLDV dapat meningkatkan kemampuan representasi matematis. Besarnya peningkatan ini dicari menggunakan rumus $\mathrm{N}$-Gain dan diperoleh besarnya $\mathrm{N}$-Gain adalah o,651. Besarnya peningkatan kemampuan representasi matematis ini berada pada kate- gori sedang.

\section{Saran}

Adapun saran yang dapat disampaikan peneliti agar penelitian selanjutnya dapat dilakukan lebih baik yaitu: guru dapat menggunakan media software GeoGebra dalam pembelajaran materi yang sesuai seperti program linier atau geometri, dan guru dapat mengatur posisi tempat duduk siswa sehingga dapat dipastikan semua siswa menerima materi yang disampaikan degan baik, para peneliti dapat melakukan penelitian mengenai faktorfaktor lainnya yang dapat meningkatkan kemampuan representasi matematis siswa, dan penelitian ini tergolong lemah karena hanya menggunakan metode pre-experimental design sehingga untuk penelitian selanjutnya diharapkan dapat menggunakan metode eksperimen.

\section{DAFTAR PUSTAKA}

Artha, R. A., Bharata, H., \& Caswita, C. (2014). Penerapan Model Pembelajaran Berbasis Masalah untuk Meningkatkan Kemampuan Representasi Matematis Siswa. Jurnal Pendidikan Matematika Unila, 2(4).

Astuty, V.W.D. \& Rudhito, M.A. (2012). Penggunaan Program GeoGebra dalam Upaya Mengatasi Kesulitan Belajar Siswa Kelas VIII E SMP N 1 Nanggulan Kulon Progo Pokok Bahasan Grafik Garis Lurus pada Pembelajaran Remedial. Proceeding dalam Seminar Nasional Matematika dan Pendidikan Matematika FMIPA UNY. Yogyakarta.

Hohenwarter, M., \& Fuchs, K. (2004). Combination of dynamic geometry, algebra and calculus in the software system GeoGebra. In Computer Algebra Systems and Dynamic Geometry Systems in Mathematics Teaching Conference.

Hohenwarter, M., Hohenwarter, J., Kreis, Y., \& Lavicza, Z. (2008). Teaching and learning calculus with free dynamic mathematics software GeoGebra. In 11 th International Congress on Mathematical Education. Monterrey, Nuevo Leon, Mexico.

Kartini. (2009). Peranan Representasi dalam Pembelajaran Matematika. Prosiding Seminar Nasional Matematika dan Pendikan Matematika. Yogyakarta: Universitas Negeri Yogyakarta.

Meltzer, D. E. (2002). The Relationship between Mathematics Preparation and Conceptual Learning Gain in Physics: A Possible Hidden Variable in Diagnostic Pretest Scores: Department of Physics and Astronomy, lowa State University, Ames, lowa 50011.

Mudzakir, H. S. (2006). Strategi Pembelajaran ThinkTalk-Write untuk Meningkatkan Kemampuan Representasi Matematik Beragam Siswa SMP. 
(Tesis yang tidak dipublikasikan, Universitas Pendidikan Indonesia, 2006).

NCTM. (2000). Principles and Standards for School Mathematics. Dikases dari http://www.ams.org/notice/200008/comm-ferini.pdf pada tanggal 1 November 2015.

Nursanti, R., \& Hartoyo, A. (2015). Pengembangan Media Pembelajaran Berbasis ICT untuk Meningkatkan Kemampuan Representasi Matematis Siswa dalam Materi SPLDV. Jurnal Pendidikan dan Pembelajaran, 4(5).

OECD. (2014). PISA 2012 Results in Result in Focus What 15-year-olds Know and What They Can Do with What They Know. Paris: OECD.

Provasnik, S., Kastberg, D., Ferraro, D., Lemanski, N., Roey, S., and Jenkins, F. (2012). Highlights From TIMSS 2011: Mathematics and Science Achievement of U.S. Fourth-and Eight-Grade Students in a International Context (NCES 2013-009). National Center for Educations Statistics, Institute of Education Science, U.S. Department of Education. Washington, DC.

Rangkuti, A.N. (2014). Representasi Matematis. Forum Pedagogik, Vol. VI. No. o1 Januari 2014.

Santoso, S. (2001). Mengolah Data Statistik Secara Profesioanl. PT. Alex Media Komputindo. Jakarta.

Sumarmo, U. (2010). Apa, Mengapa dan bagaimana Dikembangkan Peserta Didik. Makalah. FPMIPA. UPI.

Sundayana, R. (2014). Statistika Penelitian Pendidikan. Alfabeta.

Wulandari, R. (2015). Pengembangan Media Pembelajaran Matematika Interaktif Berbantuan GeoGebra dengan Pendekatan Saintifik Berbasis Penemuan Terbimbing (Guided Discovery) pada Materi Persamaan Lingkaran untuk Siswa Kelas XI. Skripsi. Pendidikan Matematika Fakultas Matematika dan Ilmu Pengetahuan Alam. Yogyakarta: Universitas Negeri Yogyakarta. 